\title{
Tanggung Jawab Moral Ilmuan dan Netralitas Ilmu
}

\author{
Asep Sopian ${ }^{1}$, Nanat Fatah Natsir ${ }^{2}$, Erni Haryanti ${ }^{3}$ \\ 1,2,3Universitas Islam Negeri Sunan Gunung Djati Bandung, Indonesia \\ E-mail: sopianasep8793@gmail.com, nanatfatahnatsir@uinsgd.ac.id,erni hk@uinsgd.ac.id
}

\begin{abstract}
Article Info
Abstract

Article History

Received: 2021-11-20

Revised: 2021-12-15

Published: 2022-01-07

This study explains the relationship between science and morals. The relationship between science and morals is so close that every human effort to investigate, discover, and improve understanding from various aspects must be guided by religious teachings and ideological understanding in attitude and action. Meanwhile, the responsibility of scientists in society is an obligation of a scientist to know social

Keywords:

Knowledge;

Moral;

Scientists;

Responsibility;

Neutrality. problems and how to solve these social problems. A scientist has a social responsibility, not only because he is a citizen whose interests are directly involved in society, but more importantly because he has a certain function in the survival of society. His function as a scientist does not stop at individual studies and knowledge but also takes responsibility so that scientific products arrive and can be utilized by the community. In essence, science has a neutral value (zero), with knowledge being neutral, the development of science can develop. So that it is not mixed with something that can make science or itself be hampered in its development.
\end{abstract}

\begin{tabular}{l}
\hline Artikel Info \\
\hline Sejarah Artikel \\
Diterima: 2021-11-20 \\
Direvisi: 2021-12-15 \\
Dipublikasi: 2022-01-07
\end{tabular}

\begin{abstract}
Abstrak
Penelitian ini menjelaskan tentang hubungan antara ilmu dan moral. Hubungan antara ilmu dan moral adalah sangat erat bahwa setiap usaha manusia untuk menyelidiki, menemukan, dan meningkatkan pemahaman dari berbagai segi harus berpedoman pada ajaran agama dan paham ideologi dalam bersikap dan bertindak. Sementara itu tanggung jawab ilmuwan di masyarakat adalah suatu kewajiban seorang ilmuwan untuk mengetahui masalah sosial dan cara penyelesaian permasalahan sosial tersebut. Seorang ilmuwan mempunyai tanggung jawab sosial, bukan saja karena dia adalah warga masyarakat yang kepentingannya terlibat secara langsung di masyarakat namun yang lebih penting adalah karena dia mempunyai fungsi tertentu dalam kelangsungan hidup bermasyarakat. Fungsinya selaku ilmuwan tidak berhenti pada penelaahan dan keilmuan secara individual namun juga ikut bertanggung jawab agar produk keilmuan sampai dan dapat dimanfaatkan oleh masyarakat. Hakikatnya ilmu itu mempunyai nilai Netral (nol), dengan ilmu itu netral maka perkembangan ilmu pengetahuan bisa berkembang. Sehingga tidak tercampuri dengan suatu hal yang dapat menjadikan ilmu atau itu sendiri menjadi terhambat dalam perkembangannya.
\end{abstract}

Kata kunci:

Ilmu;

Moral;

Ilmuan;

Tanggungjawab;

Netralitas.

\section{PENDAHULUAN}

Ilmu merupakan sesuatu yang paling penting bagi manusia, karena dengan ilmu semua keperluan dan kebutuhan manusia bisa terpenuhi secara cepat dan mudah. Dan merupakan kenyataan yang tak dapat dimungkiri bahwa peradaban manusia sangat berhutang pada ilmu. Ilmu telah banyak mengubah wajah dunia seperti hal memberantas penyakit, kelaparan, kemiskinan, dan berbagai wajah kehidupan yang sulit lainnya, dengan kemajuan ilmu juga manusia bisa merasakan kemudahan lainnya seperti transportasi, pemukiman, pendidikan, komunikasi, dan lain sebagainya. Singkatnya ilmu merupakan sarana untuk membantu manusia dalam mencapai tujuan hidupnya (Irwansyah, 2021), menurut (Ihsan, 2010) mengemukakan kata ilmu berasal dari bahasa Arab (alima) dan berarti pengetahuan. Pemakaian kata itu dalam bahasa Indonesia kita ekuivalenkan dengan istilah science. Science berasal dari bahasa latin scio, scire, yang juga berarti pengetahuan, berdasarkan pendapat diatas dapat disimpulkan bahwa ilmu adalah kumpulan pengetahuan yang disusun secara sistematis, konsisten, dan kebenarannya telah diuji secara empiris.

Kasmadi dalam (Ihsan, 2010) mengemukakan sifat ilmiah dalam ilmu dapat diwujudkan, apabila dipenuhi syarat-syarat yang intinya adalah sebagai berikut: 1) Ilmu harus mempunyai objek, berarti kebenaran yang hendak diungkapkan dan dicapai adalah persesuaian antara pengetahuan dan objeknya, 2) Ilmu harus mempunyai metode, berarti untuk mencapai kebenaran yang objektif, ilmu tidak 
dapat bekerja tanpa metode yang rapi, 3) Ilmu harus sistematik, berarti dalam memberikan pengalaman, objeknya dipadukan secara harmonis sebagai suatu kesatuan yang teratur, 4) Ilmu bersifat universal, berarti kebenaran yang diungkapkan oleh ilmu tidak bersifat khusus melainkan berlaku umum.

Menurut (Suriasumantri, 2000) mengemukakan dewasa ini ilmu bahkan sudah berada diambang kemajuan yang mempengaruhi reproduksi dan penciptaan manusia itu sendiri. Ilmu bukan lagi merupakan sarana yang membantu manusia mencapai tujuan hidupnya, namun bahkan kemungkinan mengubah hakikat kemanusiaan itu sendiri. Sebenarnya sejak saat partumbuhannya ilmu sudah terkait dengan masalahmasalah moral namun dalam perspektif atau pandangan yang berbeda, sedangkan Menurut (Darsono, 2010) mengemukakan moral adalah sistem nilai (sesuatu yang dijunjung tinggi) yang berupa ajaran (agama) dan paham (ideologi) sebagai pedoman untuk bersikap dan bertindak baik yang diwariskan dari generasi ke generasi berikutnya. Menurut (Arifudin, 2020) bahwa tujuan moral adalah mengarahkan sikap dan perilaku manusia agar menjadi baik sesuai dengan ajaran dan paham yang dianutnya. Sedangkan menurut (Sofyan, 2020) bahwa manfaat moral adalah menjadi pedoman untuk bersikap dan bertindak atau berperilaku dalam interaksi sosial yang dinilai baik atau buruk. Tanpa memiliki moral, seseorang akan bertindak menyimpang dari norma dan nilai sosial dimana mereka hidup dan mencari penghidupan.

Menurut (Surajiyo, 2009) mengemukakan moral berasal dari kata Latin mos jamaknya mores yang berarti adat atau cara hidup. Etika dan moral sama artinya, tetapi dalam penilaian sehari-hari ada sedikit perbedaan. Moral atau moralitas dipakai untuk perbuatan yang sedang dinilai. Adapun etika dipakai untuk pengkajian sistem nilai yang ada. Sementara itu (Ihsan, 2010) menyebutkan Kata moral dalam bahasa Yunani sama dengan ethos yang melahirkan etika. Sebagai cabang filsafat, etika sangat menekankan pendekatan yang kritis dalam melihat nilai (takaran, harga, angka kepandaian, kadar/ mutu, sifat-sifat yang penting/berguna) dan moral tersebut serta permasalahan-permasalahan yang timbul dalam kaitan dengan nilai dan moral itu. Berdasarkan kedua pendapat diatas dapat disimpulkan pengertian dari moral adalah merupakan kondisi pikiran, perasaan, ucapan, dan perilaku manusia yang terkait dengan nilainilai baik dan buruk.
Tanggung jawab sosial ilmuwan adalah suatu kewajiban seorang ilmuwan untuk mengetahui masalah sosial dan cara penyelesaian permasalahan sosial tersebut (Hasbi, 2021). Tanggung jawab merupakan hal yang ada pada setiap makhluk hidup. Hal demikian dapat dilihat pada manusia yang menunjukkan tanggung jawabnya dengan merawat dan mendidik anaknya sampai dewasa. Tanggung jawab terdapat juga pada bidang yang ditekuni oleh manusia, seperti negarawan, budayawan, dan ilmuwan. Tanggung jawab tidak hanya menyangkut subjek dari tanggung jawab itu sendiri, seperti makhluk hidup atau bidang yang ditekuni oleh manusia akan tetapi juga menyangkut objek dari tanggung jawab, misalnya sosial, mendidik anak, memberi nafkah dan sebagainya.

Jika dinyatakan bahwa ilmu bertanggung jawab atas perubahan sosial, maka hal itu berarti (1) ilmu telah mengakibatkan perubahan sosial dan juga (2) ilmu bertanggung jawab atas sesuatu yang bakal terjadi. Jadi tanggung jawab tersebut bersangkut paut dengan masa lampau dan juga masa depan. Yang perlu diperhatikan ialah bahwa apa yang telah terjadi sebenarnya tidak mutlak harus terjadi dan apa yang bakal terjadi tidak perlu terjadi; hal itu semata-mata bergantung kepada keputusan manusia sendiri (Ihsan, 2010).

Menurut Abbas Hama dikutip (Tanjung, 2021) para ilmuwan sebagai orang yang professional dalam bidang keilmuwan sudah barang tentu mereka juga memiliki visi moral, yaitu moral khusus sebagai ilmuwan. Moral inilah didalam filsafat ilmu disebut juga sebagai sikap ilmiah. Menurut Abbas dikutip (Surajiyo, 2009) sedikitnya ada enam sikap ilmiah yang perlu dimiliki oleh para ilmuwan yaitu: 1) Tidak ada rasa pamrih (disinterstedness), artinya suatu sikap diarahkan untuk mencapai pengetahuan ilmiah yang objektif dengan menghilangkan pamrih atau kesenangan pribadi, 2) Bersikap selektif, yaitu suatu sikap yang tujuannya agar para ilmuwan Mampu mengadakan pemilihan terhadap segala sesuatu yang dihadapi. Misalnya hipotesis yang beragam, metodologi yang masing-masing menunjukkan kekuatannya atau cara penyimpulan yang satu cukup berbeda walaupun masing-masing menunjukkan akurasinya, 3) Adanya rasa percaya yang layak baik terhadap kenyataan maupun terhadap alat-alat indra serta budi (mind), 4) Adanya sikap yang mendasar pada suatu kepercayaan (belief) dan dengan merasa pasti (conviction) bahwa setiap pendapat atau teori yang terdahulu telah 
mencapai kepastian, 5) Adanya suatu kegiatan rutin bahwa seorang ilmuwan harus selalu tidak puas terhadap penelitian yang telah dilakukan, sehingg selalu ada dorongan untuk riset dan riset sebagai aktivitas yang menonjol dalam hidupnya, 6) Harus memiliki sikap etis (akhlak) yang selalu berkehendak untuk mengembangkan ilmu untuk kemajuan ilmu dan untuk kebahagiaan manusia, lebih khusus untuk pembangunan bangsa dan negara.

Proses menemukan kebenaran secara ilmiah mempunyai implikasi etis bagi seorang ilmuan. Karakteristik proses tersebut merupakan kategori moral yang melandasi sikap etis seorang ilmuan. Kegiatan intelektual yang meninggikan kebenaran sebagai tujuan akhirnya mau tidak mau akan mempengaruhi pandangan moral. Kebenaran berfungsi bukan saja sebagai jalan pikirannya namun seluruh jalan hidupnya. Dalam usaha masyarakat untuk menegakkan kebenaran inilah maka seorang ilmuwan terpanggil oleh kewajiban sosialnya, bukan saja sebagai penganalisis materi kebenaran tersebut namun juga sebagai prototipe moral yang baik (Suriasumantri, 2000), Dalam penelitian ini akan dibahas tentang Hubungan antara ilmu dan moral, Tanggung jawab ilmuwan di masyarakat, dan Netralitas Ilmu.

\section{METODE PENELITIAN}

Sesuai dengan karakteristik masalah yang diangkat dalam penelitan ini maka penulis menggunakan Metode Riset kualitatif, yaitu menekankan analisanya pada data deskriptif berupa kata-kata tertulis yang diamati. Pendekatan kualitatif penulis gunakan untuk menganalisis kajian tanggung jawab moral ilmuan dan netralitas ilmu, maka dengan sendirinya penganalisaan data ini lebih difokuskan pada Penelitian Kepustakaan (Library Research), yakni dengan membaca, menelaah dan mengkaji buku-buku dan sumber tulisan yang erat kaitannya dengan masalah yang dibahas. Metode yang digunakan dalam kajian ini menggunakan metode atau pendekatan kepustakaan (library research), menurut Zed dalam (Na'im, 2021) bahwa studi pustaka atau kepustakaan dapat diartikan sebagai serangkaian kegiatan yang berkenaan dengan metode pengumpulan data pustaka, membaca dan mencatat serta mengolah bahan penelitian.

Jenis penelitian ini adalah penelitian kualitatif. Menurut Ibnu dalam (Nasser, 2021) penelitian kualitatif adalah suatu penelitian yang datanya dinyatakan dalam bentuk verbal dan dianalisis tanpa menggunakan teknik statistik. Berdasarkan beberapa definisi penelitian kualitatif di atas, dapat disimpulkan bahwa penelitian kualitatif adalah suatu penelitian yang datanya dinyatakan dalam bentuk verbal, tidak menggunakan angka dan analisisnya tanpa menggunakan teknik statistik.

1. Objek Penelitian

Dalam penelitian ini objek penelitian, yaitu objek formal dan objek material. Objek formal dalam penelitian ini berupa data yaitu data yang berhubungan dengan tanggung jawab moral ilmuan dan netralitas ilmu. Sedangkan objek materialnya berupa sumber data, dalam hal ini adalah tanggung jawab moral ilmuan dan netralitas ilmu.

2. Waktu Penelitian

Penelitian ini dilaksanakan pada bulan Oktober sampai dengan November tahun 2021.

3. Teknik Pengumpulan Data

Pengumpulan data yang dilakukan dengan menggunakan teknik dokumentasi yaitu mengadakan survey bahan kepustakaan untuk mengumpulkan bahan-bahan, dan studi literatur yakni mempelajari bahan-bahan yang berkaitan dengan objek penelitian. Teknik pengumpulan data menurut (Bahri, 2021) mengemukakan bahwa merupakan langkah yang paling strategis dalam penelitian karena tujuan untama dari penelitian adalah mendapatkan data. Terdapat beberapa cara atau teknik dalam mengumpulkan data, diantaranya adalah observasi dan dokumentasi. Sumber data yang digunakan dalam penelitian ini mencakup data primer dan sekunder. Menurut (Hanafiah, 2021) bahwa data primer adalah data yang dikumpulkan langsung dari individu-individu yang diselidiki atau data tangan pertama. Sedangkan data sekunder adalah data yang ada dalam pustaka-pustaka. Data primer dalam penelitian ini adalah buku tanggung jawab moral ilmuan dan netralitas ilmu, dan data sekunder didapatkan dari jurnal-jurnal baik nasional maupun internasional.

4. Alat Pengumpulan Data

Dalam penelitian ini, penulis akan menggunakan metode dokumentasi sebagai alat untuk pengumpul data karena penelitian ini adalah penelitian kepustakaan. Dengan kata lain, menurut (Arifudin, 2021) bahwa teknik ini digunakan untuk menghimpun data-data dari sumber primer maupun sekunder. 
5. Teknik Analisis Data

Analisis data tidak saja dilakukan setelah data terkumpul, tetapi sejak tahap pengumpulan data proses analisis telah dilakukan. Penulis menggunakan strategi analisis "kualitatif", strategi ini dimaksudkan bahwa analisis bertolak dari data-data dan bermuara pada kesimpulan-kesimpulan umum. Berdasarkan pada strategi analisis data ini, dalam rangka membentuk kesimpulan-kesimpulan umum analisis dapat dilakukan menggunakan kerangka pikir "induktif". Menurut (Sugiyono, 2015) bahwa metode pembahasan menggunakan metode deskriptif-analisis, yaitu menjelaskan serta mengelaborasi ide-ide utama yang berkenaan dengan topik yang dibahas. Kemudian menyajikannya secara kritis melalui sumber-sumber pustaka primer maupun skunder yang berkaitan dengan tema.

6. Prosedur Penelitian

Data pada penelitian ini dicatat, dipilih dan kemudian diklasifikasikan sesuai dengan kategori yang ada. Pendekatan yang digunakan adalah pendekatan deskriptif analitis. Menurut (Rahayu, 2020) bahwa deskriptif analitis (descriptive of analyze research), yaitu pencarian berupa fakta, hasil dari ide pemikiran seseorang melalui cara mencari, menganalisis, membuat interpretasi serta melakukan generalisasi terhadap hasil penelitian yang dilakukan. Prosedur penelitian ini adalah untuk menghasilkan data deskriptif yang berupa data tertulis setelah melakukan analisis pemikiran (content analyze) dari suatu teks. Setelah penulis mengumpulkan bahan-bahan yang berhubungan dengan masalah yang akan di bahas dalam penelitian ini, kemudian penulis menganalisis dan menarasikan untuk diambil kesimpulan.

\section{HASIL DAN PEMBAHASAN}

Dalam pembahasan ini akan dibahas tentang Hubungan antara ilmu dan moral, Tanggung jawab ilmuwan di masyarakat, dan Netralitas Ilmu.

1. Hubungan antara ilmu dan moral

Ilmu merupakan sesuatu yang paling penting bagi manusia, karena dengan ilmu semua keperluan dan kebutuhan manusia bisa terpenuhi secara lebih cepat dan mudah. Untuk apa pengetahuan yang berupa ilmu itu dipergunakan? Bagaimana kaitan antara cara penggunaan tersebut dengan kaidah-kaidah moral? Bagaimana penentuan objek yang ditelaah berdasarkan pilihan-pilihan moral?
Bagaimana kaitan antara teknik prosedural yang merupakan operasionalisasi metode ilmiah dengan norma-norma moral/ professional?

Penalaran otak orang itu luar biasa. Benarkah bahwa makin cerdas, maka makin pandai kita menemukan kebenaran, makin benar maka makin baik pula perbuatan kita? Apakah manusia yang mempunyai penalaran tinggi, lalu makin berbudi, sebab moral mereka dilandasi analisis yang hakiki, ataukah malah sebaliknya: makin cerdas maka makin pandai pula kita berdusta?

Perkembangan dan kemajuan ilmu pengetahuan telah menciptakan berbagai bentuk kemudahan bagi manusia. Namun yang menjadi pertanyaan bagi kita apakah hal itu selalu demikian? Dimana ilmu pengetahuan dan teknologinya merupakan berkah dan penyelamat bagi manusia, terbebas dari kutuk yang membawa malapetaka dan kesengsaraan? Memang dengan jalan mempelajari teknologi seperti pembuatan bom atom, manusia bisa memanfaatkan wujudnya sebagai sumber energi bagi keselamatan manusia, tetapi dipihak lain hal ini bisa berakibat sebaliknya seperti pemboman yang terjadi di Bali membawa manusia kepada penciptaan boom atom yang menimbulkan malapetaka. Menghadapi hal yang demikian, ilmu pengetahuan pada esensinya mempelajari alam sebagaimana adanya, mulai dipertanyakan untuk apa sebenarnya ilmu itu harus dipergunakan? Untuk menjawab pertanyaan tersebut, apakah para ilmuwan harus berpaling ke hakekat moral? Bahwa ilmu itu berkaitan erat dengan persoalan nilai-nilai moral.

Keterkaitan ilmu dengan nilai-nilai moral (agama) sebenarnya sejak pertumbuhannya ilmu sudah terkait dengan masalah-masalah moral namun dalam perspektif yang berbeda. Ketika Capernicus (1473-1543) mengajukan teorinya tentang kesemestaan alam dan menemukan bahwa "bumi yang berputar mengelilingi matahari" sementara ajaran agama menilai sebaliknya, maka timbullah interaksi antara ilmu dengan moral yang berkonotasi metafisik, sedangkan di pihak lain, terdapat keinginan agar ilmu mendasarkan kepada pernyataan-pernyataan yang terdapat dalam ajaran-ajaran di luar bidang keilmuan, di antaranya agama.

Timbullah konflik yang bersumber pada penafsiran metafisik ini berkulminasi pada pengdilan inkuisisi Galileo pada tahun 1633. 
Galileo (1564-1642), oleh pengadilan agama tersebut, dipaksa untuk mencabut pernyataannya bahwa bumi berputar mengelilingi matahari. Pengadilan inkuisisi Galileo ini selama kurang lebih dua setengah abad mempengaruhi proses perubahan berfikir di Eropa, dalam kurun waktu ini para ilmuwan berjuang untuk menegakkan ilmu yang berdasarkan penafsiran alam sebagaimana adanya dengan semboyan: Ilmu yang Bebas Nilai, setelah pertarungan itulah ilmuwan mendapatkan kemenangan dengan memperoleh dengan keotonomian ilmu. Artinya kebebasan dalam melakukan penelitiannya dalam rangka mempelajari alam sebagaimana adanya. Ketika ilmu dapat mengembangkan dirinya, yakni dari pengembangan konseptual yang bersifat komtemplatif disusul penerapan-penerapan konsep ilmiah ke masalahmasalah praktis (bersifat manipulatif) atau dengan perkataan lain dari konsep ilmiah yang bersifat abstrak menjelma dalam bentuk konkrit bersama teknologi, konflik antara ilmu dan moral berlanjut.

Setelah ilmu mendapatkan otonomi yang terbebas dari segenap nilai yang bersifat dogmatik, ilmu dengan leluasa dapat mengembangkan dirinya baik dalam bentuk abstrak maupun kongkret seperti teknologi. Teknologi tidak meragukan lagi manfaatnya bagi manusia. Kemudian timbul pertanyaan, bagaimana dengan teknologi yang mengakibatkan proses dehumanisasi, apakah ini merupakan masalah kebudayaan ataukah masalah moral? Apabila teknologi itu menimbulkan ekses yang negatif terhadap masyarakat?

Dihadapkan dengan masalah moral dalam menghadapi akses ilmu dan teknologi yang bersifat merusak ini para ilmuwan terbagi ke dalam dua golongan pendapat. Golongan pertama menginginkan bahwa ilmu harus bersifat netral terhadap nilai-nilai baik itu secara ontologis maupun aksiologis.Dalam hal ini tugas ilmuwan adalah menemukan pengetahuan dan terserah kepada orang lain untuk tujuan yang baik, ataukah dipergunakan untuk tujuan yang buruk. Golongan kedua sebaliknya berpendapat bahwa netralitas ilmu terhadap nilai-nilai hanyalah terbatas pada metafisik keilmuan, sedangkan dalam penggunaannya, bahkan pemilihan objek penelitian, maka kegiatan keilmuan haruslah berlandaskan asas-asas moral. Tahap tertinggi dalam kebudayaan moral manusia, ujar Charles
Darwin, adalah ketika kita menyadari bahwa kita seyogyanya mengontrol pikiran kita.

Golongan pertama ini melanjutkan tradisi kenetralan ilmu secara total seperti pada waktu era Galileo sedangkan golongan kedua mencoba menyesuaikan kenetralan ilmu secara pragmatis berdasarkan perkembangan ilmu dan masyarakat. Golongan kedua mendasarkan pendapatnya pada beberapa hal yakni: (-1) ilmu secara faktual telah dipergunakan secara destruktif oleh manusia yang dibuktikan dengan adanya dua Perang Dunia yang mempergunakan teknologi-teknologi keilmuan; (2) ilmu telah berkembang dengan pesat dan makin esotrik sehingga kaum ilmuwan lebih mengetahui tentang eksesekses yang mungkin terjadi bila terjadi penyalahgunaan; dan (3) ilmu telah berkembang sedemikian rupa dimana terdapat kemungkinan bahwa ilmu dapat mengubah manusia dan kemanusiaan yang paling hakiki seperti pada kasus revolusi genetika dan teknik perubahan sosial (social engineering). Berdasarkan ketiga hal ini maka golongan kedua berpendapat bahwa ilmu secara moral harus ditujukan untuk kebaikan manusia tanpa merendahkan martabat atau mengubah hakikat kemanusian.

Penerapan ilmu pengetahuan yang telah dihasilkan oleh para ilmuwan, apakah itu berupa teknologi, maupun teori-teori emansipasi masyarakat dan sebagainya itu, masalah memperhatikan nilai-nilai kemanusiaan, nilai agama, nilai adat dan sebagainya. Karena ilmu sudah berada di tengah-tengah masyarakat luas dan masyarakat akan mengujinya. Oleh karena itu, tanggung jawab lain yang berkaitan dengan penerapan teknologi di masyarakat yaitu menciptakan hal positif. Namun tidak semua teknologi atau ilmu pengetahuan selalu memiliki dampak positif ketika berada di tengah masyarakat. Kadangkala teknologi berdampak negatif, misalnya masyarakat menolak atau mengklaim suatu teknologi bertentangan atau tidak sejalan dengan keinginan atau pandangan-pandangan yang telah ada sebelumnya, seperti rekayasa genetik (kloning manusia) yang dapat bertentangan dengan kodrat manusia atau ajaran agama.

Dalam persoalan ini perlu ada penjelasan lebih lanjut. Bagi seorang ilmuwan jika ada semacam kritikan terhadap ilmu, ia harus berjiwa besar, bersifat terbuka untuk menerima kritikan dari masyarakat. Tugas seorang 
ilmuwan harus dapat menjelaskan hasil penelitiannya sejernih mungkin atas dasar rasionalitas dan metodologis yang tepat, masalah moral tidak bisa dilepaskan dengan tekad manusia untuk menemukan kebenaran, sebab untuk menemukan kebenaran dan terlebih-lebih lagi untuk mempertahankan kebenaran, diperlukan keberanian moral. Tanpa landasan moral maka ilmuwan mudah sekali tergelincir dalam melakukan prostitusi intelektual. Penalaran secara rasional yang telah mencapai harkatnya seperti sekarang ini berganti dengan proses rasionalisasi yang bersifat mendustakan kebenaran. Di tengah situasi dimana nilai mengalami kegoncangan ilmuwan harus tampil kedepan. Pengetahuan yang dimilikinya merupakan kekuatan yang akan memberinya keberanian. Hal yang sama harus dilakukan pada masyarakat yang sedang membangun, seorang ilmuwan harus bersikap sebagai seorang pendidik dengan memberikan contoh yang baik. Kemudian bagaimana solusi bagi ilmu yang terkait dengan nilai-nilai? Maka ilmu pengetahuan haruslah terbuka pada konteksnya, dan agamalah yang menjadi konteksnya itu. Agama mengarahkan ilmu pengetahuan pada tujuan hakikinya, yakni memahami realitas alam, dan memahami eksistensi Allah, agar manusia menjadi sadar pada hakikat penciptaan dirinya, dan tidak mengarahkan ilmu pengetahuan "melulu" pada praxis, pada kemudahmudahan material duniawi saja.

Kekuasaan manusia atas ilmu pengetahuan harus mendapat tempat yang utuh, eksistensi ilmu pengetahuan bukan "melulu" untuk mendesak kemanusiaan, tetapi kemanusianlah yang mengenggam ilmu pengetahuan untuk kepentingan dirinya dalam rangka penghambaan dirinya kepada sang Pencipta.

\section{Tanggungjawab Ilmuwan di Masyarakat}

Menurut (Suriasumantri, 2000) mengemukakan Ilmu merupakan hasil karya perseorangan yang dikomunikasikan dan dikaji secara terbuka oleh masyarakat. Penciptaan ilmu bersifat individual namun komunikasi dan penggunaan ilmu adalah bersifat sosial. Kreativitas individu yang didukung oleh sistem komunikasi sosial yang bersifat terbuka menjadi proses pengembangan ilmu yang berjalan secara efektif. Seorang ilmuwan mempunyai tanggung jawab sosial, bukan saja karena dia adalah warga masyarakat yang kepentingannya terlibat secara langsung di masyarakat namun yang lebih penting adalah karena dia mempunyai fungsi tertentu dalam kelangsungan hidup bermasyarakat. Fungsinya selaku ilmuwan tidak berhenti pada penelaahan dan keilmuan secara individual namun juga ikut bertanggung jawab agar produk keilmuan sampai dan dapat dimanfaatkan oleh masyarakat.

Jika dinyatakan bahwa ilmu bertanggung jawab atas perubahan sosial, maka hal itu berarti ilmu telah mengakibatkan perubahan sosial dan juga ilmu bertanggung jawab atas sesuatu yang bakal terjadi. Jadi tanggung jawab tersebut bersangkut paut dengan masa lampau dan juga masa depan (Ihsan, 2010).

Ilmuwan berdasarkan pengetahuannya memiliki kemampuan untuk meramalkan apa yang akan terjadi. Umpamanya saja apakah yang akan terjadi dengan ilmu dan teknologi kita di masa depan berdasarkan proses pendidikan keilmuan sekarang. Dengan kemampuan pengetahuannya seorang ilmuwan juga harus dapat mempengaruhi opini masyarakat terhadap masalah-masalah yang seyogyanya mereka sadari (Suriasumantri, 2000).

Tanggung jawab ilmu atas masa depan pertama-tama menyangkut usaha agar segala sesuatu yang terganggu oleh campur tangan ilmu bakal dipulihkan kembali. Campur tangan ilmu terhadap masa depan bersifat berat sebelah, karena sekaligus tertuju kepada keseimbangan dalam alam dan terhadap keteraturan sosial. Gangguan terhadap keseimbangan alam misalnya pembasmian kimiawi terhadap hama tanaman, sistem pengairan, dan sebagainya. Perlu diingat bahwa keberatsebelahan itu sebenarnya bukan hanya karena tanggung jawab ilmu saja, melainkan juga oleh manusia sendiri (Adib, 2010).

Seorang ilmuwan pada hakikatnya adalah manusia yang biasa berpikir dengan teratur dan teliti. Bukan saja jalan pikirannya mengalir melalui pola-pola yang teratur namun juga segenap materi yang menjadi bahan pemikirannya dikaji dengan teliti. Seorang ilmuwan tidak menolak atau menerima sesuatu begitu saja tanpa suatu pemikiran yang cermat. Disinilah kelebihan seorang ilmuwan dibandingkan dengan cara berpikir seorang awam (Amsal, 2004).

Untuk memahami ihwal tanggung jawab manusia, kiranya baik juga diketengahkan dengan singkat alam pikiran Yunani Kuno. Menurut alam pikiran Yunani Kuno, ilmu adalah theoria, sedangkan keteraturan alam 
dan keteraturan masyarakat selalu menurut kodrat Ilahi. Setiap keteraturan adalah keteraturan ilahi dan alam (karena mempunyai keteraturan) bahkan dianggap sebagai Ilahi atau sebagai hasil pengaturan Ilahi (Mudhofir, 2007).

Dibidang etika tanggung jawab sosial seorang ilmuwan bukan lagi memberikan informasi namun memberi contoh. Dia harus tampil di depan bagaimana caranya bersifat obyektif, terbuka, menerima kritik, menerima pendapat orang lain, kukuh dalam pendirian yang dianggapnya benar, dan kalau perlu berani mengakui kesalahan. Pengetahuan yang dimilikinya merupakan kekuatan yang akan memberinya keberanian. Demikian juga dalam masyarakat yang sedang membangun maka dia harus bersikap sebagai seorang pendidik dengan memberikan suri teladan (Suriasumantri, 2000), Jadi bila kaum ilmuwan konsekuen dengan pandangan hidupnya, baik secara intelektual maupun secara moral, maka salah satu penyangga masyarakat modern akan berdiri dengan kukuh. Berdirinya pilar penyangga keilmuan itu merupakan tanggung jawab sosial seorang ilmuwan.

Tanggung jawab juga menyangkut penerapan nilai-nilai etis setepat-tepatnya bagi ilmu di dalam kegiatan praktis dan upaya penemuan sikap etis yang tepat, sesuai dengan ajaran tentang manusia dalam perkembangan ilmu.

\section{Netralitas Ilmu}

Metode ilmiah merupakan prosedur yang mencakup berbagai tindakan pikiran, pola kerja, tata langkah, dan cara tehnis untuk memperoleh pengetahuan baru atau memperkembangkan pengetahuan yang ada. Prosedur yang dipergunakan para ilmuwan dalam pencarian sistematis dari pengetahuan baru dan peninjauan kembali pengetahuan yang ada.Tehnik- tehnik dan prosedur pengamatan dan percobaan yang menyelidiki alam yang dipergunakan oleh untuk mengolah faktafakta, data dan penafsirannya sesuai dengan asas- asas dan aturan tertentu.

Metode ilmiah atau proses ilmiah merupakan proses keilmuan untuk memperoleh pengetahuan secara sistematis berdasarkan bukti fisis. Ilmuwan melakukan observasi serta membentuk hipotesis dalam usahanya untuk menjelaskan fenomena alam. Prediksi yang dibuat berdasarkan hipotesis tersebut diuji dengan melakukan eksperimen. Jika suatu hipotesis lolos uji berkali-kali, hipotesis tersebut dapat menjadi suatu teori ilmiah / ilmu / Sains.

Wacana masalah netralisasi ilmu memang masih dalam perdebatan di kalangan masyarakat. Tetapi pada hakikatnya ilmu itu mempunyai nilai Netral (nol), dengan ilmu itu netral maka perkembangan ilmu pengetahuan bisa berkembang. Sehingga tidak tercampuri dengan suatu hal yang dapat menjadikan ilmu atau itu sendiri menjadi terhambat dalam perkembangannay, sedangkan netral itu sendiri ada berbagai pandangan yang pertama dalam pandangan Ontologi, yakni masalah atau hakikat netral itu sendiri. Yang mempunyai ruang lingkup tentang baik buruknya ilmu yang telah ada.

Kemudian dalam pandangan secara Epistimologi yaitu masalah bagaimana mendapatkan ilmu itu. Dan untuk mendapatkanya apakah sesuai atau malah menyimpang dari metode ilmiah. Ketika seorang ahlijanung ingin meneliti tentang jantung manusia. Ada suatu kendala apabila Dokter ini meneliti jantung selain jantung manusia seperti jantung simpanse misalnya, tentu hasilnya berbeda apabila dokter itu menggunakan jantung manusia itu. Tetapi masalahnya ada beberapa yang tidak menyetujui hal ini, dikarenakan telah keluar dari rasa kemanusiaan. Padahal tujuan awal agar data yang diperoleh Valid dan lengkap, tetapi mereka salah memandang hal tersebut.

Sedangkan yang terakhir adalah netralisasi dalam pandangan Aksiologi. ini menyangkut masalah nilai kegunaan ilmu itu sendiri. Seperti suatu hal yang sangat disesalkan oleh Albert Einsten, karena penemuannya tentang nuklir. Ternyata manusia sebagai pengkonsumsi dari hasil temuan ilmu itu telah menyimpang atau menyalahi aturan yang ada. Padahal Einsten meneliti nuklir bukan karena dia ingin menggunakannya sebagai bom / perusak, tetapi sebaliknya yaitu untuk kemaslahatan manusia sendiri. Tetapi manusia sendirilah yang telah salah menggunakan hasil pikiran Einstein itu.

Menurut saya dari wacana diatas sudah jelas nilai imu itu netral. Sehingga memudahkan dalam penelitian dan tidak akan tercampuri dari suatu hal apapun. Maksud dari Netral itu sendirikan, ilmu itu tidak bernilai baik atau buruk tetapi ilmu itu di antara keduanya. Sesuai manusia yang membawa ilmu itu. Bagaimanakah menggunakannya? Untuk apa 
ilmu itu? Siapa yang memakai ilmu itu? Semua pertanyaan itu salah satu bukti kenetralan ilmu. Karena terserah manusia itu membawa ilmu itu sendiri, terserah manusia itu bagaimana menggunakannya, dan untuk apa ilmu yang dia dapat, dan siapapun orangnya ilmu tidak terpengaruh nilainya tetap netral (nol).

Sebagai contoh, bisa diilustrasikan sebagai berikut: Kalau saya boleh menggambarkan seperti titik koordinat pada matematika. Nilai 0 (Nol) itulah ilmu atau sains. Dan hal ini terserah manusia mau digeser kemana nilai 0 (nol) itu, mau ke titik Negatif atau ke titik Positif. Itu semua terserah manusia yang menjadi konsumen ilmu yang telah ada.

\section{SIMPULAN DAN SARAN}

\section{A. Simpulan}

Dari uraian dia atas dapat disimpulkan bahwa ilmu pengetahuan adalah seluruh usaha sadar untuk menyelidiki, menemukan, dan meningkatkan pemahaman manusia dari berbagai segi kenyataan dalam alam manusia. Moral adalah sistem nilai (sesuatu yang dijunjung tinggi) yang berupa ajaran (agama) dan paham (ideologi) sebagai pedoman untuk bersikap dan bertindak baik yang diwariskan dari generasi ke generasi berikutnya. Jadi hubungan antara ilmu dan moral adalah sangat erat bahwa setiap usaha manusia untuk menyelidiki, menemukan, dan meningkatkan pemahaman dari berbagai segi harus berpedoman pada ajaran agama dan paham ideologi dalam bersikap dan bertindak. Sementara itu tanggung jawab ilmuwan di masyarakat adalah suatu kewajiban seorang ilmuwan untuk mengetahui masalah sosial dan cara penyelesaian permasalahan sosial tersebut. Seorang ilmuwan mempunyai tanggung jawab sosial, bukan saja karena dia adalah warga masyarakat yang kepentingannya terlibat secara langsung di masyarakat namun yang lebih penting adalah karena dia mempunyai fungsi tertentu dalam kelangsungan hidup bermasyarakat. Fungsinya selaku ilmuwan tidak berhenti pada penelaahan dan keilmuan secara individual namun juga ikut bertanggung jawab agar produk keilmuan sampai dan dapat dimanfaatkan oleh masyarakat.

\section{B. Saran}

Pembahasan "Tanggung Jawab Moral Ilmuan Dan Netralitas Ilmu" dalam penelitian ini masih sangat terbatas dan membutuhkan banyak masukan. Saran untuk penulis selanjutnya adalah mengkaji lebih dalam tanggung jawab moral ilmuan dan netralitas ilmu, dan studi kritis terhadap tanggung jawab moral ilmuan dan netralitas ilmu. Hakikatnya ilmu itu mempunyai nilai Netral (nol), dengan ilmu itu netral maka perkembangan ilmu pengetahuan bisa berkembang. Sehingga tidak tercampuri dengan suatu hal yang dapat menjadikan ilmu atau itu sendiri menjadi terhambat dalam perkembangannya.

\section{DAFTAR RUJUKAN}

Adib. (2010). Filsafat Ilmu. Yogyakarta: Pustaka Pelajar.

Amsal. (2004). Filsafat Ilmu. Jakarta: PT. Raja Grafindo Persada.

Arifudin, O. (2020). Psikologi Pendidikan (Tinjauan Teori Dan Praktis). Bandung: Widina Bhakti Persada.

Arifudin, O. (2021). Implementasi Balanced Scorecard dalam Mewujudkan Pendidikan Tinggi World Class. Edumaspul: Jurnal Pendidikan, 5(2), 767-775.

Bahri, A. S. (2021). Pengantar Penelitian Pendidikan (Sebuah Tinjauan Teori dan Praktis). Bandung: Widina Bhakti Persada.

Hanafiah, H. (2021). Pelatihan Software Mendeley Dalam Peningkatan Kualitas Artikel Ilmiah Bagi Mahasiswa. Jurnal Karya Abdi Masyarakat, 5(2), 213-220.

Hasbi, I. (2021). Administrasi Pendidikan (Tinjauan Teori Dan Praktik). Bandung: Widina Bhakti Persada.

Ihsan. (2010). Filsafat Ilmu. Jakarta: Rineka Cipta.

Irwansyah, R. (2021). Perkembangan Peserta Didik. Bandung : Widina Bhakti Persada.

Mudhofir. (2007). Pengenalan Filsafat: Filsafat Ilmu. Yogyakarta: Penerbit Liberty.

Na'im, Z. (2021). Manajemen Pendidikan Islam. Bandung : Widina Bhakti Persada.

Nasser, A. A. (2021). Sistem Penerimaan Siswa Baru Berbasis Web Dalam Meningkatkan Mutu Siswa Di Era Pandemi. Biormatika: 
Jurnal Ilmiah Fakultas Keguruan Dan Ilmu Pendidikan, 7(1), 100-109.

Rahayu, Y. N. (2020). Program Linier (Teori Dan Aplikasi). Bandung : Widina Bhakti Persada.

Sofyan, Y. (2020). Peranan Konseling Dosen Wali Dalam Meningkatkan Motivasi Belajar Mahasiswa Di Perguruan Tinggi Swasta Wilayah LLDIKTI IV. Jurnal Bimbingan Dan Konseling Islam, 10(2), 237-242.

Sugiyono. (2015). Metode Penelitian Pendidikan (Pendekatan Kuantitatif,. Kualitatif dan $R \& D)$. Bandung : CV. Alfabeta.
Surajiyo. (2009). Filsafat Ilmu dan Perkembangannya di Indonesia. Jakarta: Bumi Aksara.

Suriasumantri. (2000). Filsafat Ilmu Sebuah Pengantar Populer. Jakarta: Pustaka Sinar Harapan.

Tanjung, R. (2021). Kompetensi Manajerial Kepala Sekolah Dalam Meningkatkan Kinerja Guru Sekolah Dasar. JIIP-Jurnal Ilmiah Ilmu Pendidikan, 4(4), 291-296. https://doi.org/10.54371/jiip.v4i4.272 